\title{
Beata Karpińska-Musiał
}

Wydział Filologiczny Uniwersytetu Gdańskiego

lingbet@ug.edu.pl

\section{TUTORIAL AKADEMICKI W NAUKACH FILOLOGICZNYCH NA TLE ZAŁOŻEŃ INTERAKCYNEGO DYSKURSU GLOTTODYDAKTYCZNEGO - KRYTYCZNA ANALIZA RÓŻNIC I PODOBIEŃSTW}

\section{Academic tutorial in philology in the context of the interactive discourse in glottodidactics - critical analysis of differences and similarities}

The article is a comparative study of a few chosen criteria of interactive discourse in glottodidactics, as formulated by Anna Seretny (2014) and the specificity of personalized one-to-one language teaching in a tutorial. The thesis stated by the author claims that tutorial, due to its different type of teacher-student interaction, varying epistemological background and distinctive levels of interactive rhetoric (e.g. its less instructional and more natural character) is not an obvious space for developing language competence. On the other hand, it may, as the space for very individual and intense learning context, promote development of communicative skills and critical thinking, thus helping to meet cognitive aims of the curriculum in philological studies at the university.

Keywords: academic tutorial, interactive discourse in glottodidactics, tutorial, interaction, relations in teaching, epistemology of knowledge, language competences

Słowa kluczowe: tutoring akademicki, interakcyjny dyskurs glottodydaktyczny, tutorial, interakcja, relacja w dydaktyce, epistemologia wiedzy, kompetencje językowe 


\section{Wprowadzenie}

Artykuł jest propozycją rzeczowej dyskusji na temat przystawalności formuły nauczania spersonalizowanego w postaci akademickiego tutorialu do kształcenia językowego na poziomie studiów filologicznych. Argumentacja oraz zastosowane elementy analizy skupiają się wokół tylko jednego poziomu interakcji językowej w klasie - komunikacji między uczniem a nauczycielem. Podstawą analizy jest przyjęcie wybranych kryteriów przypisywanych specyfice interakcyjnego dyskursu glottodydaktycznego (Seretny 2014; M ihułka 2015) oraz pracy tutorialowej, czyli dialogicznemu spotkaniu studenta z tutorem w formule jeden na jeden (np. Axer 2015; Czekierda, Fingas i Szala (red.) 2015). Obie formy pracy dydaktycznej zastosowane w nauczaniu języka obcego charakteryzują się wielością zróżnicowanych metod, technik i narzędzi, z których część może być wspólna na poziomie aplikacyjnym, ale których użycie uwarunkowane jest także nieco innymi przesłankami epistemologicznymi. Za źródło podjętej dyskusji można więc przyjąć pytanie: czy kształcenie językowe w obrębie języka obcego na poziomie akademickim może mieć formę edukacji spersonalizowanej, czy też raczej jej skuteczność zyskuje na tradycyjnej pracy grupowej? Co więcej, w jakim stopniu na efektywność kształcenia glottodydaktycznego wpływa specyfika interakcji między uczniem a nauczycielem w obu przypadkach?

Pytanie to wydaje się pozornie proste i nasuwa dość oczywistą odpowiedź, jeśli powołać się na szerokie badania glottodydaktyczne w zakresie indywidualizacji kształcenia, autonomii ucznia i nauczyciela, akwizycji języka pierwszego i drugiego, a także budowania kompetencji komunikacyjnej w sposób intensywny i pozbawiony zewnętrznych czynników zakłócających. Do tych czynników należą chociażby dyscyplina w grupie, nierówny poziom kompetencyjny uczniów w mixed-ability classes (Komorowska 1999), różne etapy wiedzy wyjściowej (comprehensible input) oraz różne tempo osiągania poziomu produkcji (comprehensible output) (Krashen 1985 w: Seretny 2014: 37). Wydawałoby się więc oczywiste, że maksymalna indywidualizacja procesu glottodydaktycznego poskutkuje wyższą efektywnością w zakresie przyswajania języka oraz budowania płynności językowej. W niniejszym artykule przyjmuję jednak tezę, że tutorial - jako przykład spersonalizowanego kształcenia - nie jest w pełni kompatybilny z wybranymi aspektami kształcenia językowego i w związku z tym nie stanowi najlepszego rozwiązania dla edukacji językowej sensu stricto.

Nie chodzi tylko o to, że w pracy indywidualnej z uczniem brak jest okazji do pracy w zespołach czy też w typowych dla ćwiczeń językowych parach. Praca tutorialowa eliminuje również możliwość gamifikowania zajęć, tak popularnego ostatnio w dydaktyce, nie tylko językowej. Bez wątpienia aspekty czysto metodyczne świadczą o tym, że praca i nauka języka obcego w grupie 
Tutorial akademicki w naukach filologicznych na tle założeń interakcyjnego...

ma wiele zalet. Jednocześnie znane są zalety pracy indywidualnej w zakresie nauczania i uczenia się języków, w przypadku której nauczyciel jest w stanie poświęcić uczniowi całą uwagę. W takiej sytuacji znacznie szybciej dokonuje działań korekcyjnych, a także ma przestrzeń do budowania motywacji ucznia przez modyfikację poziomów interakcji w zależności od osobowości ucznia, jego strategii uczenia się oraz tempa pracy. M oja argumentacja w pierwszej części artykułu nie wchodzi zatem w polemikę z powyższymi faktami na temat procesu glottodydaktycznego, lecz kieruje się w stronę jego kilku wybranych kryteriów (wyróżnionych poniżej w treści artykułu), które czynią go procesem interakcyjnym.

M oim celem jest próba odpowiedzi na pytanie, dlaczego charakter dyskursu glottodydaktycznego jest odmienny od specyfiki interakcji uczeń-nauczyciel w dialogu tutorskim. Owe kryteria przyjmuję tutaj częściowo za Seretny (2014), a dodatkowo powołuję się na elementy koncepcji dyskursywności w glottodydaktyce zidentyfikowane przeze mnie oraz Izabelę Orchowską (2014). Natomiast poziomy interakcji w relacji „uczeń-mistrz” w tutorialu wyszczególnione zostały m.in. przez Sajdak (2013), Czekierdę (2015), Grzegorczyka (2016), Jendzę (2016), Karpińską-M usiał (2015, 2016a), Karpińską-M usiał i Dziedziczak-Foltyn (2014), Sarnat-Ciastko (2015). Przedstawiona w niniejszym artykule odmienność dotyczyć będzie zatem następujących kryteriów: kierunku interwencji językowej, rodzaju dysonansu poznawczego i jego roli w autokorekcie ucznia, modyfikacji tzw. wiedzy wyjściow ej (comprehensible input) oraz produkcji (modified output), ze szczególnym zwróceniem uwagi na rodzaje modyfikacji: jej językową oraz pozajęzykową formę (a w niej na zależność od głębokości relacji i zaangażowania obu stron dialogu dydaktycznego). Istotna jest też kwestia typu informacji zwrotnej (feedback), jakiego udziela się w interakcyjnym dyskursie glottodydaktycznym oraz w tutoringu akademickim. Nie mniej ważne będą też dla mnie kwestie epistemologiczne, wśród których na szczególną uwagę w kontekście różnicowania dyskursu glottodydaktycznego i retoryki tutorialu zasługują rodzaje refleksyjności, a także jej rola w samopoznaniu oraz przekazywaniu wiedzy versus jej współtworzeniu. Przy tej okazji w końcowej części artykułu odniosę się do wybranych koncepcji wiedzy, roli języka w poznaniu oraz filozoficznych paradygmatów (np. podstaw interakcjonizmu symbolicznego G. H. Meada), które mogą określać poszczególne rodzaje interakcji w obu rozważanych formach pracy dydaktycznej. To właśnie bowiem w obszarze epistemologii kryje się, moim zdaniem, duża część odpowiedzi na pytanie, dlaczego tutoring, rozumiany jako anglosaski model edukacji spersonalizowanej, jest formą kształcenia odmienną od interakcyjnego dyskursu glottodydaktycznego. Ma jednak dla uczącego się, co także postaram się wykazać, wiele innych walorów edukacyjnych na płaszczyźnie rozwijania kompetencji komunikacyjnej oraz poznawczej, z myśleniem krytycznym oraz współtworzeniem wiedzy 
na czele. Wiedzy nie tylko językowej, ale też metajęzykowej i metajęzykoznawczej. Przez ten fakt, jak i przez głębokość interakcji nawiązywanej w trakcie spotkania, tutorial stanowi doskonałą formę pracy i nauki akademickiej na poziomie zaawansowanym, co de facto powinno być punktem wyjścia, jeśli mówimy 0 uniwersyteckim poziomie kształcenia językowego.

\section{Interakcyjny dyskurs glottodydaktyczny}

Jak zauważa Seretny (2014: 38), dyskurs interakcyjny w glottodydaktyce „to ustrukturalizowane, a zatem podlegające prawom spójności gatunkowej, zachowania językowe uczestników określonego zdarzenia komunikacyjnego (zob. Hymes 1972)". Badaczka przypomina także, powołując się na Pałuszyńską (2011), że jest to rodzaj kodu społecznego, w ramach którego wchodzący ze sobą w interakcję uczestnicy procesu dydaktycznego negocjują pewne znaczenia i funkcje swoich wypowiedzi. Niezaprzeczalnie zatem jest to ten rodzaj komunikacji, w którym wykorzystuje się określone zwroty formulaiczne, strategie komunikacyjne i znaczenia uznane za typowe dla danego kontekstu komunikacyjnego. Jednocześnie jednak Seretny przyznaje, że jako dyskurs edukacyjny zakłada on raczej przyswajanie wiedzy, a nie jej tworzenie (2014: 38). Dodatkowo jako dyskurs glottodydaktyczny nosi on, jak zauważa Niżegorodcew (1991), znamiona jeszcze bardziej ustrukturyzowanego kodu z racji swoistej sztuczności wobec języka naturalnego (częste symulacje kontekstualne), nierównego rozkładu kompetencji ucznia i nauczyciela (to nauczyciel jest wzorem i źródłem form poprawnych) oraz z reguły ściśle określonego celu kształcenia. W zależności od poziomu kształcenia językowego, jest to albo porozumienie na jego wyższych etapach, albo zaledwie zrozumienie na niższych szczeblach edukacji.

Specyfikę dyskursu glottodydaktycznego w nieco szerszej perspektywie opisują też autorka tego tekstu i Izabela Orchowska (Karpińska-M usiał i Orchowska 2015). Zajmując się szeroko rozumianą konstytucją dyskursywnego funkcjonowania glottodydaktyka jako profesjonalisty w swojej dyscyplinie i środowisku zawodowym oraz naukowym, uznałyśmy interakcyjny dyskurs w klasie za jedną z odsłon dyskursu, w ramach którego nauczyciel się porusza i jakim jest zobowiązany operować. Nazwałyśmy tę odsłonę językiem, „,którym posługują się nauczyciele, zwracając się do swoich uczniów/studentów w celu wprowadzenia materiału będącego przedmiotem nauczania/kształcenia, ustosunkowywania się do i oceny produkcji studentów" (2015: 254). Jednocześnie odróżniłyśmy dyskurs szkolny od dyskursu dydaktyczno-akademickiego, który „cechuje ukierunkowanie na cele poznawcze i naukowy sposób myślenia oraz interpretowania rzeczywistości" (2015: 254).

Dyskurs interakcyjny, czyli odbywający się bezpośrednio pomiędzy uczniem a nauczycielem w trakcie kształcenia językowego, naszym zdaniem 
plasuje się obok co najmniej trzech innych typów dyskursu w glottodydaktyce: naukowego, oświatowo-administracyjnego i publicznego, które także występują w obszarze funkcjonowania glottodydaktycznego i stanowią jego części składowe (Karpińska-M usiał 2015: 253-254). Jest to o tyle istotne, że poszerza perspektywę analizy zachodzących w glottodydaktyce interakcji realizowanych przez określony dyskurs. Zbliża nas też do postulatu, sformułowanego przykładowo przez Klus-Stańską w odniesieniu do każdej dydaktyki przedmiotowej, dotyczącego tego, by badania nad komunikacyjną stroną dydaktyki w klasie szkolnej poszerzyć z czysto lingwistycznych o społeczno-krytyczne, uwzględniające również odbijające się w interakcjach w klasie kwestie ideologiczno-polityczne (Klus-Stańska 2010: 165). Podążając w tym kierunku, przejdę do sedna argumentacji, którym jest przekonanie, że właśnie strona społeczna interakcji, objęta innymi kryteriami ewaluacji efektywności procesu dydaktycznego w obszarze języka obcego, odróżnia retorykę tutorialu od interakcyjnego dyskursu glottodydaktycznego.

\section{Tutorial akademicki w naukach filologicznych}

Tutoring jako forma spersonalizowanej edukacji wywodzi się z tradycji anglosaskiej, gdzie w XVIII-wiecznej Anglii zapewniano potomkom elitarnych rodzin wykształcenie w duchu Artes Liberales. Tutor to nauczyciel, mistrz, kapitan okrętu poznania i zarazem mądry przewodnik po meandrach pytań i wątpliwości mniej lub bardziej dociekliwej jednostki. Zarówno tradycja, jak i zindywidualizowany charakter kształcenia, pozbawiony wielu aspektów społecznych, ale z drugiej strony umożliwiający całkowitą adaptację strategii nauczania do możliwości i umiejętności ucznia, czyni tutoring elitarną metodą kształcenia. Współcześnie jest ona realizowana z reguły w formie zajęć indywidualnych w edukacji nieformalnej, półformalnej oraz w ramach wszelkich projektów szkolnych na różnych etapach kształcenia (przygotowania do olimpiad, konkursów, korepetycje). Jak twierdzi Budajczak, powołując się na informacje zebrane np. przez Czekierdę i in. (2009), „tutoring, w różnych dlań formułach, bywa zestawiany, łączony, a niekiedy utożsamiany z takimi edukacyjnymi działaniami, [...] jak korepetytorstwo, wychowawstwo, doradztwo, coaching, mentoring, nauczanie grupowe, a nawet nauczanie zbiorowe" (Budajczak 2015: 170). W obszarze szkolnictwa wyższego praca ze studentem w formule jeden na jeden zwyczajow o od bywa się na konsultacjach, seminariach dyplomowych i magisterskich, a na studiach doktoranckich w formie konsultacji naukowych doktoranta z promotorem. Od wielu już dekad, bo od lat 70. XX w., to właśnie edukacja językowa znana jest z tzw. lekcji prywatnych, konwersacji lub też korepetycji, podczas których nauczyciel stara się jak najefektywniej, z pełnym zaangażowaniem 
doskonalić umiejętności komunikacyjne oraz językowe podopiecznego. Liczne językowe szkoły prywatne w Polsce już od lat 90. ubiegłego stulecia, kiedy zaistniały na rynku edukacyjnym, oferują naukę w grupach 2-3 osobowych lub nawet serie kursów indywidualnych. Niewątpliwie jest to formuła, która jeszcze długo będzie się cieszyła powodzeniem w obszarze glottodydaktyki. Czy jest to jednak tutoring w pełnym tego słowa znaczeniu?

Edukacja spersonalizowana, mimo iż często praktykowana według wspomnianych wyżej formuł systemowych, zaczęła w ostatniej dekadzie przybierać pogłębiony wymiar teoretyczny i praktyczny. W kontekście teoretycznym wiąże się to z rosnącą świadomością pedagogiczną w wielu tzw. wspólnotach epistemicznych (epistemic communities), w tym też glottodydaktycznej, rozumianych jako grupy ekspertów oraz praktyków merytorycznie uprawnionych do tworzenia i postulowania pewnych sądów naukowych. Wzrostowi tej świadomości sprzyja niezwykle szybki rozwój wielu dyscyplin i nauk, które tworzą kompilację przesłanek tłumaczących skuteczność (lub jej brak) dobrej edukacji uczniów o różnych kapitałach kulturowych, społecznych oraz ekonomicznych. Nauki neurobiologiczne oraz psychologiczne wnoszą do pedagogiki wiedzę na temat ludzkiej pamięci, procesów kognitywnych, uczenia się mózgu oraz etapów akwizycji języka (macierzystego i obcego) w zależności od etapu rozwoju poznawczego lub psychospołecznego człowieka (zob. np. Piaget 1966; Krashen 1985; Erikson 2004). Psychologia humanistyczna mówi o zmiennych warunkujących uczenie się, zależnych od poziomów motywacji i - co ważne - od poziomów interakcji, od których zależna jest skuteczność nauki (np. Dauber 2001). Niebagatelny wkład w promocję tutoringu ma także nurt psychologii pozytywnej, w której rozwój człowieka postrzegany jest jako przede wszystkim dążenie do spełnienia jego zawsze obecnych, a często nieodkrytych mocnych stron i umiejętności. Interakcjonizm symboliczny rozwijany przez Blumera (2007), oparty na założeniach socjologa M eada i nawiązujący do pragmatyzmu Jamesa i Deweya (o którym jeszcze wspomnę poniżej), poszerza w stopniu niezwykłym spektrum wiedzy na temat okoliczności i uwarunkowań kształcenia w dzisiejszym społeczeństwie, także postrzeganych przez pryzmat struktur społecznych i tworzenia znaczeń w interakcji symbolicznej, nie tylko na poziomie językowym.

Tutoring zatem staje się swoistą matrycą terminologiczną i koncepcyjną, która obejmuje coraz więcej znaczeń. Przede wszystkim poszerza rozumienie personalizacji i przenosi je z czysto indywidualnych technik metodycznych na całościowe, kompleksowe podejście do ucznia. Jak pisze Czekierda w jednym ze swoich opracowań na temat tutoringu, „Tutoring to metoda indywidualnej opieki nad podopiecznym oparta na relacji mistrz-uczeń, która dzięki integralnemu spojrzeniu na rozwój człowieka stara się o pełny rozwój jego potencjału" (Czekierda 2015: 20). Z adekwatnością stosowania pojęcia 
Tutorial akademicki w naukach filologicznych na tle założeń interakcyjnego...

„metoda” wobec tutoringu polemizuje Jendza (2016), twierdząc, że sednem tutoringu jest sama unikatowość spotkania dwóch podmiotów i żywy proces interakcji, a nie użyte w nim narzędzia czy techniki, które mają profil czysto metodyczny. Autor ten postuluje zaniechanie definiowania tutoringu jako dyskursu instrumentalno-dydaktycznego i przeniesienie go w obszar narracji humanistycznej o głębokim wymiarze antropologicznym. Tutoring doczekał się wielu ujęć teoretycznych w obszarach pedagogiki i socjologii edukacji (np. Sajdak 2013; Karpińska-M usiał i Dziedziczak-Foltyn 2014; Kowalczuk-Walędziak 2015; Sarnat-Ciastko 2015). Jednym z moich własnych przykładów ideologicznego zakorzenienia tutoringu jest osadzenie go w filozofii tożsamości narracyjnej Ricœura (Karpińska-M usiał 2015: 133; 2016a: 74), drugim zaś próba usytuowania tutoringu między siłami działającymi w polu biurokratycznym Bourdieu, które w kontekście relacji różnych kapitałów społecznych szczegółowo opisał Wacquant (2012) (zob. też Karpińska-M usiał 2016a: 52). W pierwszym przypadku, w dużym uproszczeniu tutoring zostaje oparty na wskazanej przez filozofa dialektyce ludzkiej tożsamości typu niezmiennego idem oraz zmiennego, procesualnego ipse. Owa dialektyka tworzy nieustanną transformacyjną narrację, w której człowiek, tutaj podopieczny, „samo-opowiada” swą tożsamość, czyli inaczej uczy się, tworząc narracje o sobie samym w nowych kontekstach. Jest w głębokiej interakcji ze sobą samym wskutek działań edukacyjnych. W drugim przypadku, tutoring wyznacza pewną trajektorię działania edukacyjnego, prowadzącą od zainicjowanych oddolnie (przez tutora) działań budujących kapitał kulturowy ucznia (przez personalistyczny dialog i rozwój intelektu) w kierunku inwestowania w kapitał ekonomiczny. W efekcie kształcenia jednostka staje się bowiem silnym, samosterownym i dobrze przygotowanym absolwentem o kompetencjach spełniających także warunki dyktatu rynku pracy.

To założenie przeprowadza nas na praktyczną, aplikacyjną stronę tutoringu, która także przeżywa swoisty renesans i redefinicję w Polsce. Za sprawą kilku firm szkoleniowych ${ }^{1}$, skupiających edukatorów, którzy doświadczyli tego typu kształcenia na uczelniach anglosaskich, praca tutorska zaopatrzona została w autorskie i specjalistyczne narzędzia i techniki oraz teoretyczną podbudowę wspartą osobistym doświadczeniem. Powstał określony know-how, którym eksperci i wykwalifikowani trenerzy dzielą się w coraz szerszym zakresie w środowiskach szkolnych oraz akademickich. Tutoring przekształcił się z indywidualnej, mało ustrukturyzowanej lekcji-korepetycji w potężny mechanizm dydaktyczny, obejmujący ekspercką wiedzę i określone umiejętności po stronie tutora: językowe, komunikacyjne, merytoryczne, a przede wszystkim - relacyjne.

\footnotetext{
${ }^{1}$ Największymi ośrodkami szkolącymi w zakresie tutoringu są na rynku polskim Collegium Wratislaviense oraz Kolegium Tutorów, oba z Wrocławia.
} 
W kształceniu filologicznym tutorial, jako proces złożony z reguły z kilku lub kilkunastu indywidualnych spotkań tutora ze studentem, tworzy przestrzeń dla mocno pogłębionej interakcji językowej i merytorycznej, noszącej znamiona dialogu osobowości. Jak piszemy z Izabelą Orchowską, cytując za Ostrowską (2011: 260), tutor w obszarze glottodydaktycznym²:

[...] nie tylko przyczynia się do rozwoju poznawczego swoich studentów, ale również konstruuje z nimi wspólnie relacje interpersonalne i reprezentacje rzeczywistości m.in. przez podejmowane przez siebie działania komunikacyjne i przejawy tzw. myślenia dyskursywnego. Z tym ostatnim mamy do czynienia wówczas, gdy wiedza osiqgana jest stopniowo, na bazie uznanej wcześniej wiedzy za sprawq ogniw i operacji pośrednich, i jest ono inspirowane rozmow $q$, dialogiem, dyskusjq, wymianq argumentów, polemikq (Karpińska-M usiałi Orchowska, 2015: 247).

Tak współtworzona wiedza i budowane w dialogu w sposób negocjacyjny kompetencje komunikacyjne stanowią zupełnie inną formę kształcenia językowego zarówno od tzw. korepetycji, jak i od tradycyjnej lekcji grupowej. Priorytetem nie jest tu bowiem metodyczna nauka poprawności i płynności językowej, mimo iż operuje się słowem mówionym i pisanym w sposób bardzo obszerny (elementem kształcenia filologicznego jest chociażby pisanie esejów). W następnym podrozdziale postaram się przedstawić bardziej szczegółowo, dlaczego, wedle kryteriów wymienionych wyżej, tutorial nie stanowi bezpośredniego odpowiednika interakcyjnego procesu glottodydaktycznego. W ostatniej części podejmę próbę - też przez epistemologiczne przesłanki - podkreślenia jego innych atutów, prowadzących do podobnego celu: doskonalenia wiedzy i umiejętności, a dodatkowo jeszcze postaw.

\section{Porównanie wybranych aspektów interakcji w procesie glottodydaktycznym lekcyjnym (grupowym) i w tutorialu}

Jak wspomniałam wyżej, różnicowanie tutorialu i tradycyjnej lekcji językowej (a także indywidualnej lekcji typu „korepetycje”) można prowadzić na wielu poziomach, znajdując zarówno różnice, jak i podobieństwa w zakresie stosowanych technik komunikacyjnych, sposobów ewaluacji osiągnięć czy też budowania kompetencji językowych. Zgodnie z przyjętą w tym artykule tezą zakładam jednak, że tutorial nie jest kompatybilny z wybranymi aspektami

\footnotetext{
${ }^{2}$ Należy mieć na uwadze, że przytoczona definicja tego, co dzieje się poznawczo i strukturalnie w tutorialu na poziomie dyskursywnym, dotyczyć może różnych treści przedmiotowych i dyscyplin. Tutorial filologiczny wyróżnia się tym, że przy tej okazji na określonym poziomie - doskonalone są kompetencje językowe i komunikacyjne.
} 
Tutorial akademicki w naukach filologicznych na tle założeń interakcyjnego...

kształcenia językowego oraz że podstaw ową różnicującą go cechą jest inny rodzaj interakcji pomiędzy uczniem/studentem a nauczycielem, wynikający z innych przesłanek metodycznych, poznawczych oraz epistemologicznych, „panujących" w relacji tutorskiej. Wybrane przeze mnie kryteria o mocno metodycznym charakterze, związane bezpośrednio z procesem akwizycji i uczenia się języka obcego, to - odwołując się do przykładów podanych przez Seretny (2014) - kierunek korekcji i interwencji językowej, sposób modyfikacji wiedzy wyjściowej (input) oraz produkcji (output), a także rodzaj i skuteczność określonego typu informacji zwrotnej. Ponadto zasadniczą rolę w kształtowaniu interakcji na poziomie lekcji oraz zajęć tutorskich odgrywa poziom i specyfika refleksji u ucznia oraz nauczyciela/tutora, które decydować mogą o poziomie zaangażowania oraz stopniu rozwoju poznawczego u podopiecznego. Przyjrzyjmy się teraz każdemu z tych obszarów.

Kierunek interwencji w przypadku kształcenia czysto językowego jest określony przez pozycję i kompetencję nauczyciela, który jest wzorem poprawnej informacji wyjściowej i który dokonuje restrukturyzacji frazeologii, struktur lub leksyki stosowanej przez ucznia w procesie glottodydaktycznym (Seretny 2014: 42). Zdaniem M ihułki (2015: 88) „te niesymetryczne prawa uczestnictwa w komunikacji lekcyjnej wynikają jednak nie ze złej woli nauczyciela, lecz z ram typowych dla środowiska szkolnego, które nakładają na nauczyciela i na uczniów wypełnianie właśnie takich ról". W tutorialu, jako spotkaniu dialogicznym, kierunek dokonywania owej korekty nie jest tak ściśle określony i przyjmuje się, że uczestnicy w tutorialu funkcjonują na zasadzie tzw. nierównego partnerstwa. Nierówność nie dotyczy jednak wyłącznie poziomu świadomości językowej, ale raczej wiedzy eksperckiej połączonej z miękkimi kompetencjami relacyjnymi oraz sztuką wydobywania wiedzy, wspierania przez odpowiednie zadawanie pytań, negocjowania znaczeń nie tylko semantycznych, ale przede wszystkim symbolicznych oraz kulturowych. Negocjacja ta dopuszcza interwencję także ze strony podopiecznego w formie pytań uściślających lub prowokowania nowych kwestii. Tutorial w naukach filologicznych to interakcja, której celem jest zgłębianie określonych obszarów wiedzy literackiej, językoznawczej lub translatorycznej z użyciem narzędzi językowych. Zakłada się przy tym, że w tym procesie kompetencjajęzykowa rośnie niejako przy okazji i w dużej mierze opiera się na autokorekcie studenta. Co najważniejsze, restrukturyzacja językowa nie stanowi priorytetu w dialogu tutorskim i wręcz nie powinna burzyć określonego wątku lub toku myślenia rozwijanego u uczestnika tutorialu. W pracy nad esejem studenta nawet błędów językowych nie poprawia się od razu, lecz dopiero w kolejnej, często ostatniej fazie jego czytania i analizy. Celem pracy z esejem tutorskim jest bowiem krytyczna dyskusja nad poruszanym zagadnieniem, nawet jeśli jest to, przykładowo, zagadnienie językoznawcze. Zgodnie z tym, co pisze Klus-Stańska, „sam dyskurs staje się wówczas interpretowalnym 
wydarzeniem, powiązanym ze społeczno-politycznym kontekstem, który w dyskursie się wyraża" (Klus-Stańska 2010: 146). Badaczka twierdzi, że w ten sposób buduje się także dyskurs dydaktyki jako subdyscypliny naukowej, w której w sposób szczególny uruchamia się refleksja dydaktyczna³.

Natomiast modyfikacja może i powinna nastąpić w przypadku, gdy błędy językowe są rażące lub utrudniają płynną komunikację związaną z poruszanym tematem. Odbywa się ona jednak z użyciem innych "narzędzi" w procesie lekcyjnym/korepetytorskim aniżeli w tutorskim. Naczelną rolę odgrywa tutaj rodzaj udzielanej informacji zwrotnej i sposób jej przekazywania uczniowi. Według Seretny, w przypadku edukacji językowej w klasie (lub też w indywidualnym kontakcie nastawionym na trenowanie kompetencji) główną rolę sprawczą ma feedback negatywny, czyli albo zwrócenie uwagi na błąd, co ma doprowadzić do autokorekty ucznia, albo samoistne załamanie komunikacji z racji niezrozumienia przekazu (najczęściej symulowanego przez nauczyciela). W każdym przypadku zachodzi konieczność zmodyfikowania informacji semantycznej, gramatycznej, leksykalnej czy fonetycznej. U ucznia, zdaniem badaczki, powinny wystąpić wówczas mechanizmy autokorekty lub też uniki strategiczne, w zależności od obranej strategii uczenia się (np. mechanizmy substytucji często stosowane przez uczniów uzdolnionych). Poleganie na potrzebie autokorekty ucznia jest jednak obarczone dużym ryzykiem, zależy bowiem od indywidualnego podejścia każdego ucznia do swojego procesu kształcenia i poziomu jego autorefleksji. M iędzy innymi z tego powodu w tutoringu nie stosuje się mechanizmu negatywnej informacji zwrotnej i bazuje się przede wszystkim na feedbacku pozytywnym. Element swoistego przymusu, jakim jest chociażby funkcja powtarzanego fragmentu wypowiedzi ucznia ze skorygowaną formą językową, nie może mieć miejsca w dialogu tutorskim, gdyż stoi to w sprzeczności z jego poznawczymi założeniami ideowymi. Tutoring jest edukacją opartą przede wszystkim na wzmacnianiu dobrych i mocnych stron ucznia. Redukcja niekompetencji odbywa się pośrednio i za pomocą bardzo delikatnych mechanizmów perswazji lub pracy z pytaniami, opartych na przykład na treściach zawartych w eseju. Korekta językowa, jeśli w ogóle do niej dochodzi, następuje na końcu konkretnego spotkania i nie jest dokonywana przez indukcję wzorca poprawnego, ale eksplicytnie przez dedukcję i analizę. Wykonuje się ją też tylko wówczas, gdy błąd językowy faktycznie utrudnia przekaz i zrozumienie treści, czyli skupiając się raczej na znaczeniu (meaning negotiation) niż na samej formie językowej (form negotiation) ${ }^{4}$.

\footnotetext{
${ }^{3}$ Analogicznie to samo dotyczy budowania dyskursu glottodydaktyki w zależności od tego, czy dyskutowane są zagadnienia z obszaru dydaktyki jo, czy zagadnienia stricte językoznaw cze skierowane na analizę dyskursu, czy zagadnienia z obszaru dydaktyki ogólnej.

${ }^{4} \mathrm{O}$ negocjacjach skupionych na formie lub na znaczeniu, dokonywanych celem modyfikacji komunikacji produkowanej w dyskursie, pisze Seretny (2014: 44).
} 
Tutorial akademicki w naukach filologicznych na tle założeń interakcyjnego...

M odyfikacja jest też z reguły dokonywana za pomocą innych narzędzi: w kształceniu językowym jest to najczęściej bezpośrednia modyfikacja językowa, płynąca prosto od nauczyciela. W przypadku tutoringu modyfikacja i negocjacja znaczenia mogą przebiegać przez korekty strukturalne, ale dużo większe znaczenie i częstsze zastosowanie (obustronnie u nauczyciela i ucznia) ma formuła parajęzykowa. Dotyczy to przede wszystkim, zgodnie z opinią Seretny, ucznia, który korzysta z własnych strategii uczenia się, ma różny poziom wrażliwości na własny błąd lub porażkę komunikacyjną, wynikający często z cech osobowości. Istotna jest tu również świadomość schematów dyskursywnych, a także stopień zaangażowania w proces wymiany znaczeń oraz cały proces edukacyjny (Seretny 2014: 44). A te w przypadku procesu tutorskiego są inne aniżeli w typowym procesie glottodydaktycznym, co wynika chociażby z różnic w stopniu dokonywanej w obu typach dyskursu refleksji językowej i poznawczej.

W sytuacji zajęć klasowych zachodzi bowiem swoista sztuczność dyskursu glottodydaktycznego, z czym zgadzają się np. Niżegorodcew (1991), a w najnowszych badaniach także M ihułka (2015). Jak zauważa ta druga, „,[M imo] upływu 30 lat od początku przełomu komunikacyjnego w nauczaniu języków obcych w Polsce, dyskurs interakcyjny na lekcji języka obcego trudno uznać za naturalny czy nawet zbliżony do naturalnego. Ów naturalny dyskurs interakcyjny nie jest więc stanem faktycznym, cechą każdej lekcji języka obcego, lecz raczej niedoścignionym, choć dość iluzorycznym celem" (M ihułka 2015: 8889). Jest to dyskurs często instruktażowy, korekcyjny lub symulacyjny, służący aranżowaniu sytuacji komunikacyjnych. Refleksja, rozumiana bardziej jako mechanizm autokorekty językowej, zachodzi na poziomie struktury języka i wiąże się głównie z poziomem kompetencji językowej oraz zasobnością słownika mentalnego ucznia. Podczas tutorialu natomiast refleksyjność jest rozumiana bardziej jako „aktywność poznawcza drugiego rzędu”, która dokonuje się poprzez uznanie ważkiej roli oraz bezpośrednie zastosowanie mowy wewnętrznej. Ta z kolei jest możliwa dzięki językowi naturalnemu przy przekonaniu, że „świadome, refleksyjne myślenie nie jest możliwe do zrealizowania bez istotnego udziału języka naturalnego" (Gut 2013: 402).

Język naturalny zatem, a nie publiczny i formalny, jest podstawą refleksyjnego myślenia prowadzącego do wzrostu wiedzy i kompetencji, wyciągania wniosków naukowych, myślenia krytycznego, czyli w ogólnym sensie - rozwoju poznawczego. Korekta i autokorekta na spotkaniu tutorskim nie mają bezpośrednio językowego charakteru. Zachodzą one u jednostki raczej wskutek indywidualnego dysonansu poznawczego (często modyfikacji teorii naiwnych) związanego z dyskomfortem w danym obszarze wiedzy lub rozumienia teorii, a nie w efekcie językowej korekty instruktażowej tutora. W każdym przypadku rozwój kompetencji i wiedzy następuje poprzez środki językowe, z tą różnicą, 
że w przypadku procesu glottodydaktycznego jest to głównie interakcja między mniej kompetentnym uczniem a nauczycielem, który panuje nad jego procesem udoskonalania językowego. W przypadku tutorialu akademickiego reifikacja świata następuje poprzez język, ale uczeń korzysta dużo bardziej autonomicznie z mowy wewnętrznej dla poszerzenia spektrum znaczeń kulturowych i symbolicznych, które wyraża w języku, jedynie przy okazji udoskonalając jego formę. Poznawcza funkcja języka prowadzi nas do różnych konceptualizacji pojęć, a zatem także wiedzy i dalej opisu świata, które z kolei kategoryzowane są w ramach określonych paradygmatów lub perspektyw epistemologicznych.

\section{Epistemologiczne uwarunkowania interakcji na poziomie klasowego dyskursu glottodydaktycznego oraz indywidualnego tutorialu akademickiego}

Polemika między koncepcjami wiedzy plasuje się w obszarze epistemologii nauki niezwykle szerokiej, obejmującej teorie poznania, wiedzy, prawdy, logiki i filozofii. Czerpią z niej nauki filologiczne, społeczne i nauki o życiu, kiedy chcą uzasadnić określone podstawy paradygmatyczne badań zarówno empirycznych, jak i teoretycznych. Glottodydaktyka jako nauka empiryczna niewątpliwie wpisuje się m.in. innymi w paradygmaty refleksyjności (Beck, Giddens i Lash 2009; Schoen 1983 i in.), interpretatywizmu, międzykulturowości (Karpińska-M usiał i Orchowska, 2015), w paradygmat zmiany (Fullan 1991) czy też paradygmat konstruktywistyczny. Na użytek niniejszego artykułu chciałabym pochylić się jednak nad następującymi dialektycznymi teoriami epistemologicznymi: klasyczną definicją wiedzy a pragmatyzmem, infallibilizmem a kontekstualizmem, eksternalizmem a internalizmem oraz reliabilizmem a obiektywizmem (Paprzycka 2013: 117-150). Koncepcje te, same będące ciekawymi językowymi kalkami lub neologizmami, mogą tłumaczyć - w omawianych tutaj dwóch formułach pracy dydaktycznej - zróżnicowanie podejść do kształcenia językowego, a także jego efektywności. Indukują też zupełnie inne rozumienie interakcji uczeń-nauczyciel w obu przypadkach.

Z jednej z wielu klasycznych definicji wiedzy wynika, że „o wiedzy możemy mówić tylko wtedy, gdy nasze przekonania odzwierciedlają to, jak się rzeczy w świecie mają" (Paprzycka 2013: 122). Warunki uznania praw dziw ości takiej wiedzy stanowią warunek przekonania, warunek prawdziwości i warunek uzasadnienia. Wszystkie trzy podlegają sporom same w sobie. Na przykład samo „uzasadnienie" podlega dalszym dyskusjom teoretyków: może być wystarczające przy odpowiedniej wiedzy Podmiotu, pozwalającej na uznanie czegoś za wiedzę prawdziwą (tu jest bliska pragmatyzmowi), a może odwoływać się do tzw. infallibilizmu, czyli "posiadania świadectw niezawodnych" (Paprzycka 2013: 124). Należałoby zastanowić się, czy strukturalna modyfikacja 
produkcji (output) w nauczaniu językowym nie opiera się na tego typu koncepcji niezawodności poprzez odwoływanie się do językowego wzorca idealnego i jedynego poprawnego. Można zaryzykować stwierdzenie, że instruktaż językowy w dyskursie glottodydaktycznym bliższy jest pojęciu infalliblizmu, sugerującemu nieomylność obiektywną, niż elementowi jednostkowego przekonania o prawdziwości danego sądu czy też stosowności użytej struktury językowej. Tutorial jest natomiast formą pracy, w której do głosu dochodzą właśnie przekonania jednostki, będące podstawą negocjacji znaczeń, przez co stają się bliższe kontekstualizmowi oraz tzw. reliabilizmowi Goldmana. Reliabilizm głosi, że „wiedza Podmiotu to jego prawdziwe przekonania uzyskane za pomocą rzetelnych czy wiarygodnych (reliable) procesów przekonaniotwórczych (belief-forming processes)" (Paprzycka 2013: 135). Wśród nich Goldman wymienia spostrzeganie w normalnych warunkach, klarowną pamięć, poprawne wnioskowanie, introspekcję (Paprzycka 2013: 135), na przeciwległym biegunie stawia zaś na przykład myślenie życzeniowe czy zgadywanie oparte na emocjach. Można tutaj dopatrzyć się analogii do nauki w procesie tutorskim, gdzie uczeń uczy się przede wszystkim wnioskować, argumentować, analizować i syntetyzować. Jednocześnie, jeśli przyjmiemy, że praca w tutorialu w większym stopniu oparta jest na przekonaniach, niż odnosi się do obiektywnych faktów językowych, to uznamy też tzw. internalistyczny warunek prawdziwości wiedzy, w opozycji do eksternalistycznego, gdzie mało jest miejsca na refleksję, a za niepodważalne przyjmuje się fakty zewnętrzne (w tym językowe).

Kierując się taką typologizacją jako jedynie próbą znalezienia odniesień stylu procesów dydaktycznych do uwarunkowań epistemologicznych, można skonstatować, że tak jak kształcenie językowe w swej naturze dyskursu glottodydaktycznego odnosiłoby się raczej do obiektywnej pracy na strukturach językowych, klasycznej definicji wiedzy i eksternalizmu, tak dialog tutorski można by osadzić w paradygmatach kontekstualizmu, internalizmu i pracy w oparciu o przekonania. Zarówno tutoring, jak i dyskurs klasowy mają swój pragmatyczny cel i przez to także znajdują uzasadnienie w teorii racjonalizmu pragmatycznego (zob. Pierce, Dewey, James). Z tą różnicą, że w tutorialu znajdujemy użyteczność tworzonych przekonań (reliabilizm) w celu konstruowania nowych sądów i ich nieustannego nadbudowywania na obecną wiedzę (oraz kompetencję), a w dyskursie klasowym jest to bezkolizyjna komunikacja językowa na coraz wyższym poziomie operacjonalizacji języka.

Niezależnie od osadzenia w teorii, obie formy pracy indukują określone postawy u ucznia i nauczyciela oraz wpływają na styl interakcji personalnej. W ujęciu epistemologii obiektywistycznej i infallibilistycznej, trudno o równoprawny dialog między uczniem a nauczycielem. Pozostaje on wciąż w ramach postulatywnego definiowania idealnej sytuacji w klasie/grupie. Oczywiście edukacja 
akademicka określa styl tej sytuacji i czyni go w wielu aspektach innym niż w klasie szkolnej (wiek i doświadczenie uczniów, staż edukacyjny). M imo tego jednak interpretacja aktów komunikacji, ich kierunek, rodzaj dyskursu i udzielania informacji zwrotnej podlegają bardziej deterministycznym kanałom przepływu informacji i wiedzy aniżeli w przypadku indywidualnego tutorialu akademickiego. Za społeczny wymiar procesu dyskursywnego (kierunek komunikacji, rodzaj dialogu, negocjowanie znaczeń) zachodzącego w obu przypadkach można uczynić odpowiedzialnym pewne przesłanki interakcjonizmu symbolicznego według Meada, jednak to właśnie w tutorialu znajduje on swoje dużo bardziej widoczne odzwierciedlenie. Dlaczego?

Interakcjonizm symboliczny jest uznany w naukach socjologicznych za potężny paradygmat określający charakter budowania społecznej struktury w wymiarach makro oraz mikro. Określa się go jako nurt czysto interpretatywny i odbiegający od deterministycznych, strukturalno-funkcjonalnych teorii tworzenia relacji społecznych. Zakłada, że wszelkie znaczenia pojawiają się w procesie interakcji społecznej, oddziaływania na siebie poszczególnych członków społeczeństwa w trakcie komunikacji (np. Blumer 2007). I to właśnie te społeczne negocjacje (znaczeń, gestów, symboli), odbywane najczęściej za pomocą intuicji językowych w komunikacji, stają się podstawą budowania norm oraz reguł społecznych, a nie odwrotnie. Takim mikrowymiarem wzajemnego oddziaływania społeczno-językowego jest tutorial akademicki. To w trakcie tego spotkania dwóch jednostek o określonej jaźni (wiedzy, kompetencjach i przekonaniach) zachodzi czytanie gestów, odbieranie znaczeń, ich przetwarzanie i budowanie nowych. Ma też miejsce wchodzenie tutora i podopiecznego w określone role, które pozwalają na ową wymianę w sposób dużo bardziej swobodny aniżeli w procesie grupowym nastawionym na z góry ustalony cel. W swoich dużo bardziej partnerskich rolach nauczyciel i tutor budują swoje nowe jaźnie poprzez nieustanną interpretację przyjmowanych znaków symbolicznych w procesie autorefleksji i konstrukcji. Jest to proces mocno nieustrukturyzowany i nieprzewidywalny, prowadzący po obu stronach do odkrywania nowych potencjalnych symboli, nazw, interpretacji (literatury, poezji, teorii czy też mechanizmów językowych w przypadku kształcenia filologicznego). Jest więc zrozumiałe, że tego typu interakcja odbiega od korekcyjno-modyfikującego dyskursu interakcyjnego w klasowym procesie glottodydaktycznym, którego celem jest doskonalenie przede wszystkim kompetencji językowej i komunikacyjnej.

\section{Podsumowanie}

Interakcyjność procesu glottodydaktycznego można analizować z wielu perspektyw: czysto językowej, metodyczno-pedagogicznej oraz najszerszej - epistemologicznej. 
Sama dydaktyka może przyjąć formę procesu grupowego lub cyklu indywidualnych spotkań tutorskich. W każdym z tych przypadków, dyskutowanych w powyższym artykule, zachodzą jednak inne uwarunkowania, pozwalające na różne kierunki modyfikacji produkcji językowej, inną formę kształcenia płynności komunikacyjnej oraz przede wszystkim innego typu relację między nauczającym a nauczanym. Są to zjawiska związane z rodzajem partnerstwa, w jakie wchodzi nauczyciel z uczniem w przypadku pogłębionej relacji tutorskiej. Uwarunkowania te odróżniają dialog tutorski od dotychczas definiowanej struktury interakcyjnego dyskursu klasowego w glottodydaktyce, na co szczególnie wpływ ma kilka przytoczonych w artykule kategorii: kierunek modyfikacji struktur językowych, brak lub obecność strukturalnego instruktażu funkcjonalnego, bazowanie na pozytywnej lub negatywnej informacji zwrotnej, inna przestrzeń dla refleksyjności (poprzez dysonans poznawczy i wgląd w siebie w tutorialu, natomiast w dyskursie glottodydaktycznym - automatyzacja procesu autokorekty językowej), a także inne podstawy epistemologiczne. Tutoring akademicki w naukach filologicznych może służyć doskonaleniu językowemu, jednak nie jest formułą opartą na zasadach typowego procesu glottodydaktycznego, a zachodzący w jego ramach dyskurs relacyjny między uczniem a tutorem rządzi się innymi kryteriami i przesłankami. Wnioski te wyprowadzone zostały jednak w obszarze teoretycznym, co mogłoby stanowić interesującą implikację dla komparatystycznych badań empirycznych w tej sferze. Dla przykładu, mogłaby to być krytyczna analiza dyskursu stosowanego w studium przypadku (spotkania tutorskiego) w zestawieniu z dyskursem interakcyjnym podczas akademickich językowych zajęć grupowych.

\section{BIBLIOGRAFIA}

Axer, J. 2015. "Opracowanie modelu tutoringu w ramach studiów międzyobszarowych. Tutoring a kultura akademicka, cz. II". (w) Raport końcowy z realizacji projektu systemowego "Strategia wprowadzania i oceny międzyobszarowych studiów i badań w uczelniach w kontekście reform szkolnictwa w Polsce" (POKL.04.01.03-00-002/11), cz. 7: Opracowanie modelu tutoringu w ramach studiów międzyobszarowych, Warszawa: Wydział "Artes Liberales".

Beck U., Giddens A. i Lash S. 2009. M odernizacja refleksywna. Polityka, tradycja i estetyka w porządku społecznym nowoczesności. Warszawa: PWN.

Blumer, H. 2007. Interakcjonizm symboliczny. Perspektywa i metoda. (tłum. G. Woroniecka). Kraków: Zakład Wydawniczy "Nomos".

Budajczak, M. 2015. „Tutoring a edukacja domowa”. (w) Tutoring. Teoria, praktyka, studia przypadków. (red. P. Czekierda, B. Fingas i M. Szala). Warszawa: Wolters Kluwer, str. 169-178.

Czekierda, P. 2015. „Czym jest tutoring?”. (w) Tutoring. Teoria, praktyka, studia przypadków. (red. P. Czekierda, B. Fingas i M. Szala). Warszawa: Wolters Kluwer, str. 15-35. 
Czekierda, P., Budzyński, M., Traczyński, J., Zalewski Z i A. Zembrzuska (red.). 2009. Tutoring w szkole. Wrocław: Towarzystwo Edukacji Otwartej.

Czekierda, P., Fingas, B. i M. Szala (red.). 2015. Tutoring. Teoria, praktyka, studia przypadków. Warszawa: Wolters Kluwer.

Dauber, H. 2001. Obszary uczenia się w przyszłości. Perspektywy pedagogiki humanistycznej.

(tłum. J. Marnik i M. Wawrzak-Chodaczek). Kraków: Oficyna Wydawnicza „Impuls”.

Erikson, E. 2004. Tożsamośća cykl życia. (tłum. M. żywiecki). Poznań: Wydawnictwo Zyski S-ka.

Fullan, M. 1991. The M eaning of Educational Change. London: Teachers College Press. Grzegorczyk, G. 2016. „Tutoring w perspektywie kontekstowo-ekologicznej”. (w) W trosce o jakość w ilości. Tutoring oksfordzki w Uniwersytecie Gdańskim. (red. B. Karpińska-M usiał). Kraków: Wydawnictwo LIBRON, str. 95-112.

Gut, A. 2013. „Rola języka w poznaniu”. (w) Przewodnik po epistemologii. (red. R. Ziemińska). Kraków: Wydawnictwo WAM, str. 381-422.

Hymes, D. 1972. „On communicative competence”. (w) Sociolinguistics. (red. J. B. Pride i J. Holmes). Harmondsworth, str. 269-293.

Jendza, J. 2016. „Tutoring w uniwersytecie - pomiędzy nabywaniem a tworzeniem znaczeń w procesie studiowania". (w) W trosce o jakość w ilości. Tutoring oksfordzki w Uniwersytecie Gdańskim. (red. B. Karpińska-Musiał). Kraków: Wydawnictwo LIBRON, str. 29-60.

Karpińska-M usiał, B. 2015. „Tutoring akademicki - pomiędzy epistemą a doxą. Tożsamość metody w kontekście kształcenia uniwersyteckiego". (w) Tutoring. Teoria, praktyka, studia przypadków. ( red. P. Czekierda, B. Fingas i M. Szala). Warszawa: Wolters Kluwer, str. 123-139.

Karpińska-M usiał, B. 2016a. Edukacja spersonalizowana w uniwersytecie. Ideologia instytucja - dydaktyka - tutor. Kraków: Wydawnictwo LIBRON.

Karpińska-M usiał, B. 2016b. (red.) W trosce o jakość w ilości. Tutoring oksfordzki w Uniwersytecie Gdańskim. Kraków: Wydawnictwo LIBRON.

Karpińska-M usiał, B. 2016c. (red.) Studenckim piórem w tutorskim kałamarzu. Tutoring akademicki w Uniwersytecie Gdańskim. Kraków: Wydawnictwo LIBRON.

Karpińska-M usiał, B. i A. Dziedziczak-Foltyn. 2014. „At Student's service - Tutoring and Coaching as innovative methods of academic education in Poland" EDULEARN 14 - ELECTRONICIATED PROCEEDINGS. http://www.projektiq.ug.edu.pl/wp-content/ uploads/2014/03/At-students-service-BKM usia\%C5\%82-ADFoltyn.pdf [6.02.2017].

Karpińska-M usiał, B. i I. Orchowska. 2014. „Świadomość przedmiotowa i epistemologiczna nauczyciela-refleksyjnego praktyka z perspektywy polskiej glottodydaktyki". Neofilolog 43(1): 25-38.

Karpińska-M usiał, B. i l. Orchowska. 2015. „Profesjonalizm nauczyciela akademickiego na studiach neofilologicznych w Polsce wobec zjawiska wielodyskursywności w glottodydaktyce". Neofilolog 45(2): 245-257.

Klus-Stańska, D. 2010. Dydaktyka wobec chaosu pojęć i zdarzeń. Warszawa: Wydawnictwo Akademickie „Żak”.

Komorowska, H. 1999. M etodyka nauczania języków obcych. Warszawa: WSiP. 
Kowalczuk-Walędziak, M. 2015. „Badania tutoringu w opinii nauczycieli akademickich perła z lamusa czy perła do lamusa?". (w) Tutoring. Teoria, praktyka, studia przypadków. (red. P. Czekierda, B. Fingasi M. Szala). Warszawa: Wolters Kluwer, str. 140-158. Krashen, S.1985. The Input Hypothesis: Issues and Implications. London: Longman. M ead, G. H. 1975. Umyst, osobowość, społeczeństwo. (tłum. Z Wolińska). Warszawa: PWN. M ihułka, K. 2015. „Naturalna komunikacja na lekcji języka obcego - stan rzeczywisty czy niedościgniony cel?". Języki Obce w Szkole 2/2015: 82-89.

Niżegorodcew, A. 1991. Dyskurs interakcyjny a kompetencja komunikacyjna w języku obcym. Kraków: Wydawnictwo UJ.

Ostrowska, U. 2011. „Dyskurs w edukacji akademickiej”. Przegląd Pedagogiczny 1(25): 258-266.

Pałuszyńska, E. 2011. „Tekst, sytuacja, kontekst w dyskusji”. (w) Teksty i podteksty w nauczaniu języka polskiego jako obcego - 3. Acta Universitatis Lodziensis. Kształcenie Polonistyczne Cudzoziemców, t. 18. (red. B. Grochala i M. Wojenka-Karasek), str. 43-53.

Paprzycka, K. 2013. „Pojęcie wiedzy”. (w) Przewodnik po epistemologii. (red. R. Ziemińska). Kraków: Wydawnictwo WAM , str. 176-150.

Piaget, J. 1966. Narodziny inteligencji dziecka. Warszawa: PWN.

Ricœur, P. 2005. 0 sobie samym jako innym. (tłum. B. Chełstowski). Warszawa: PWN.

Sajdak, A. 2013. Paradygmaty kształcenia studentów i wspierania rozwoju nauczycieli akademickich. Teoretyczne podstawy dydaktyki akademickiej. Kraków: Oficyna Wydawnicza "Impuls".

Sarnat-Ciastko, A. 2015. Tutoring w polskiej szkole. Warszawa: Difin S.A.

Schön, D. A. 1983. The Reflective Practitioner. How Professionals Think in Action. New York: Basic Books.

Seretny, A. 2014. "Rola efektu zwrotnego w dydaktycznym dyskursie interakcyjnym”. Acta Universitatis Lodziensis. Kształcenie Polonistyczne Cudzoziemców, t. 21, str. 37-50.

Wacquant, L. 2012. „Trzy kroki w stronę historycznej antropologii faktycznie istniejącego neoliberalizmu". Praktyka Teoretyczna nr 5: 129-151. 